\title{
REFLECTION OF SELF-ASSESSMENT IN TECHNICAL EDUCATION AT THE CZECH PRIMARY SCHOOLS
}

\section{Dominika STOLINSKÁ - Pavlína NAKLÁDALOVÁ}

\begin{abstract}
The paper presents the part of outputs, which were made by behavioral method - analysis of educational process in technical education at primary schools. We focused on methods of pupil's assessment in the content from transformation the passive acceptation of teacher's assessment the pupil's outputs to the active cooperation in assessment process and the final part is self-assessment by pupil.
\end{abstract}

Key words: self-assessment, primary school, technical education, analysis of educational process

\section{REFLEXE SEBEHODNOTÍCÍCH PROCESŮ V TECHNICKÉ VÝCHOVĚ V PROSTŘEDÍ ČESKÉ PRIMÁRNÍ ŠKOLY}

Resumé: Článek předkládá dílčí výstupy behaviorální metody analýzy vyučovacího procesu v technické výchově na primární škole. Pozornost je věnována způsobům hodnocení žákovy aktivity se snahou o postupnou transformaci pasivního přijetí učitelova zhodnocení výsledku $\mathrm{k}$ aktivnímu spolupodílení se na procesu hodnocení až k samostatnému sebehodnocení žáka.

Klićová slova: sebehodnocení, primární škola, technická výchova, analýza vyučovacího procesu

\section{Introduction}

Throughout the history has been the importance of school undeniable. Not otherwise it is today. The school as an institution providing training in the spirit still current humanistic education. It is based on the principles by Demokritos and Platon tradition in education. (Blaško, 2013) Humanistic concept is based on learning things, phenomena and facts together with self-making of human personality. The ideal goal of the course is to design so harmoniously develop of pupils who are creative and responsible for their actions.

This objective is difficult (if not impossible) to achieve without the active involvement of both human factors in the educational process without the pupil and his teacher. We can say that the quality and condition of interaction between teacher and pupil affects the whole process of pupil's socialization. First idea has much connection with Vygotsky's concept of the 30s of the 19th century about affecting of social influence and activities of the child, which interact with each other. (Vilánek, 2007) Helus (2007) even calls the idea that organization of the systematic effect should be given to every man to society constituted as a social individual. All these basic ideas are integrated into the currently applied constructivist approach to education, which is a mean and vision of modern Czech schools.

\section{The vision of education as a starting concept of the research}

For evaluation of the usage of the educational process at the level of the pupil's self-controlled (as in every other level) must be based on the strategic approaches, which presents the National Education Development Programme (ie. Bílá kniha, 2001). This document, which is the instrument of educational policy of our country, states as a general education goals for personal development of individuals, their integration into society and the formation of the citizen and his preparation for working life. Given the focus of the contribution is decisive for us the first two planes.

If you move further and if we look more specific than a general level, then theoretically we can rely on vision for primary education, which is inspired by the international context, from which it is possible to extract the basic goal - a multi-faceted development of the pupil with the maximum development of potentialities. (Preschool and Primary Education in the European Union, 1996) Here was already approaching to our starting the project, namely that the school should encourage socialization and personalization of the pupil's development. 
This can be achieved with efficient evaluation in the educational process. Teacher's evaluation is influenced by numerous factors which are part of the relationship between teacher and pupil. Among the most important determinants include understanding the teacher and the pupil himself from the unfolding overall conception of teaching (teaching strategies). If a teacher works as a single evaluator, is the process of learning viewed only by one (although expert) view. In the event that in the spirit of contemporary pedagogy we perceive the pupil as a co-operator in the educational process, then its necessary participation in the evaluation of the results of learning activities. Evaluation of their work will enable to pupils to regulate their activity, thus affecting their learning and they learn to accept responsibility for their results. (Kolář, Šikulová, 2009)

\section{Evaluations in Technical Education}

In order to diagnose a pupil's performance and result during the technical education has to answer the questions: What specifically monitor and evaluate and what action to take in order to assess pupil's performance fair, reliable and efficient? (Bajtoš, Pavelka, 1999) The answers to these questions characterize applied teaching strategies which include the interaction between teacher and pupils. Evaluation of teaching has a very specific role, because without evaluation processes cannot be developed further. Evaluation has different forms and from that unfolding function.

Teacher's evaluation is influenced by a large number of facts that are part of the relationship between teacher and pupil. Self-reflection can then be seen as a process of feedback control, which leads to the linking of existing knowledge with the current through the re-equipping of events and facts and their critical assessment. (Kolář, Šikulová, 2009)

Pupils are all their activities got into a situation where they have to decide for specific process solutions. An integral part of every decision-making process is evaluation. This gives to pupil's feedback, and thus formed his idea of the accuracy of the procedures that have chosen to implement the task. Now the choice of own way of solving the task supports the development of pupils' creativity and fine-tuned his understanding of teaching situations and contexts. Providing an appropriate reflection of the teacher can lead pupils to self-directed activities. These activities cannot be at the primary school pupils expected from day to day. It is a long process that has its own laws.

\section{Pupil's self-reflection as a part of self- assessment in technical education}

Self-assessment in the context of technical education at primary school is one of the teaching methods, in which is the pupil confronts with own views on him or with the views of teachers or other pupils. From a psychological point of view, it is a representation of emotional perception of competence. (Blatný, 2010) Selfreflection can be defined as generally conscious introspection within the meaning of introspection on the basis of which the relationship with oneself. The path to self-reflection leads the pupil through teacher assessment. He is one of the main factors affecting the self-assessment activities of pupils. The following chart outlines the consistency of individual evaluation steps. The pupil's self-assessment cannot be expected without cause - move from the teacher assessment through self-assessment using the indicative questions the teacher to pupil individually organized self-reflection.

Chart no. 1: Consistency reflexive practices

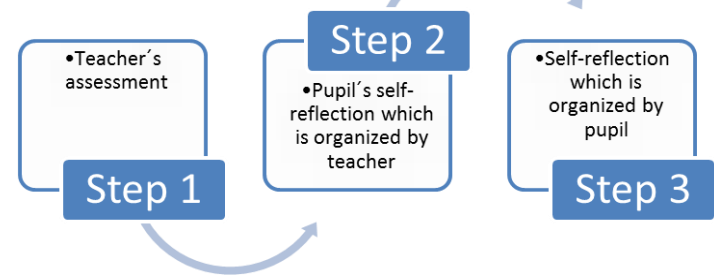

The evaluation of skills needs to be developed systematically, for example through the abovementioned indicative reflective questions. These issues include questions such as: What new things I learned? What I succeeded? In what situation I'm insecure? How do I react when I know something? What should I concentrate more? Why I got better / worse? (adjusted according to Koláŕ, Šikulová, 2009)

Thus formulated questions may be regulated, motivated and cognitive function during the learning process and at its conclusion. Despite the pupil's self-assessment cannot fully substitute teacher assessment but in the educational process has its justification. Teacher's assessment and self-assessment of pupil should be in balance with each other and mingle because the effort of every teacher should be moving towards independence and responsibility for the pupil's actions. 
Thoughtful best way of the pupil's "spin" from self-controlled to uncontrolled process may differ for every teacher and every class. It is possible to observe the enlargement strategy, in the sense of deepening, indicative questions (or items) from several general to specific, or vice versa.

\section{Reflection 4 levels of evaluation in a real environment at primary schools} 5.1 Design Research

As a major research goal we set to monitor reflexive strategies of teachers and pupils in a real environment at primary schools.

The data were collected in 50 primary school classes of Moravian and Olomouc Region, which were selected based on the multiple selection (random cities and random selection of primary schools in the different cities).

In order to most effectively capture the main issue being addressed was chosen from the available techniques standardized behavioral technique offers the possibility of detailed and very specifically analyze the area addressed in the educational process.

Was therefore selected by Bellack's interaction microanalysis, which professor Arno A. Bellack together with staff from Columbia University developed and subsequently verified in 1966. This is a special formal language, through which it is possible to relatively objectively capture the action in the classroom teaching and write them simultaneously, almost orchestral score. (Tollingerová, 1971)

In the implementation of the research data collection was carried out so that the recording of the lesson was recorded on a dictaphone literally rewritten in this special language. Performed was both frequency and sequence analysis. Of the identified codes were interpreted answers to the research questions.

\subsection{Research questions}

Through the implementation of research, we look for the answers to the following questions:

VO1: How does a course of instruction? Who and what is it doing?

VO2: Who is the main factor controlling the educational process?

VO3: How does the process of evaluation and self-evaluation during the educational process?

On the basis of the presented strategy, research design, we reached results that are interpreted below.

\subsection{Interpretation of research outputs Progression of the educational process at the level of teacher and pupil}

The theoretical background is the assumption that the teacher always tries to provide the pupil feedback to inform him about his actions. For the first time the results present the value of teachers, it is clear that the teacher focuses on the pupil and the determination of his activity. These are data that may be considered desirable. As a not so desirable are outputs, which testify to the fact that a teacher spends a lot of time with verbal expressions (unfortunately, often in situations without notice values for the pupil - just to speak).

For the second they present a pupil chart readings, which also can be evaluated as encouraging - a pupil spends in the educational process much time with cognitive activities, which are already apparent from the very essence of the educational process, and it is also desirable value indicative of room for verbal expression of pupils.

\section{Sequence analysis reflecting the learning style}

The structure of outputs as the most consistently under three learning styles. It is a communication rules that teachers are required. The most frequently observed method where the teacher presents the activity, pupils react to this stimulus and then the teacher will provide feedback. Sometimes the teacher simply insisted on the reaction of pupils without this structure capped feedback. As the third largest independent flooring appeared requirements.

Other readings will then disperse to other interaction structures. It is worth mentioning at least one more value - last. It tells the true interaction between teacher and pupil. Teacher specified activities respond to pupils, the teacher then provides feedback. This does not stop all communication, because the feedback pupils react again and again they are given feedback. The fact that the teaching style is equipped with the fourth highest measured value supports the idea of a partnership approach with two main factors teaching.

\section{Bearer of educational events}

The vision of the educational process resulting from the contemporary school reform talks about an equal share of activity between teacher and pupil. The research results show that the teacher is still the most active parts of the process. Nevertheless, let us evaluate that a shift has 
occurred in this area. Bellack (1966) in his microanalysis activity separates that to $85 \%$ of teachers and $15 \%$ for the pupil. Here it should be noted that the results of the analysis by Bellack with his own research we compare very carefully, because they are not identical samples - Bellack his observations realized at primary and preprimary schools. In the 80 s of the 20th century was carried out another similar research by Bártková (1983) and he has focused on primary school, while the outputs were very close to Bellack. Our values obtained are encouraging and are going towards reform. But the question is whether difference between teacher and pupil activity is not desirable (especially at primary school).

\section{The evaluation process}

Now we come to the final item on which we have directed all the time - revealing assessment strategies in the educational process. For the first time we present the values of the pupil. Here is a very interesting space seems to assign truth values learning activities - i.e. "how successful are pupils." Another value is a reflection or analysis of their own activities, or a combination of reflection and evaluation. As a very encouraging accumulation value is high frequency speech expressing his own opinion and space for a justification of this view.

For teachers we can observe the evaluation process similar values (although with greater frequency, but this stems from the very nature of the percentage of teachers' speech in the definition of the educational process - as Bearer of educational events). The teacher therefore very often assigns truth values to pupil's performance provides a reflection of their activities, or there is a combination of the teacher's actions, whereas the frequency of symptoms, when the teacher calls his own opinion, was measured up to a half less, which we attribute pursuit of objectivity in teacher evaluation. Expressing justification of self-evaluation is a proof kind of constructive approach to evaluation. For the second part we show that teachers are actually trying to work with the idea of perception mistakes as a natural process of pupil learning.

\section{Final summary}

For the final summary, we chose reflection research questions. First, it is possible to evaluate that quite visibly reduce the percentage difference in activity between the teacher and pupil in the educational process. He tends to respect and interest of the pupil. Returning to the scheme no. 1 - Consistency reflexive practice, it is possible to say that the teacher continues to use a more traditional model assessment (see Sequence analysis of teaching style and Frequency analysis of the evaluation process). Either the teacher assesses himself, or gives space to the pupil. There, and it's a shame so often interact in the evaluation - that would lead teacher pupil, who would this approach could acquire self-assessment strategies, and eventually "break away" from the teacher's only looking at the success of his teaching efforts. Perhaps it stems from the need teachers to keep his role as the main and leading factor of the educational process, and thus not losing the lead role of the evaluator.

The importance of teachers in the educational process is immeasurable, but there are situations that can facilitate pupil in many ways the process of socialization and personalization. As outlined through the research results in the evaluation strategies can still be seen considerable shortcomings.

\section{Literatura}

[1] Bajtoš, J., Pavelka, J. Základy didaktiky technickej výchovy. Prešov: FHPS, 1999. ISBN 80-88722-46-2.

[2] Bárková, H. (1983) Didaktické aspekty interakce učitel-žák na základní škole. Ostrava: PdF.

[3] Bellack, A. A., et al. (1966) The Language of the Classroom. New York: Teachers College Press.

[4] Bílá kniha: Národni program rozvoje vzděláváni v České Republice. (2001) Praha: Tauris.

[5] Blaško, M. (2013) Kvalita v systéme modernej výučby. Košice: KIP TU. Dostupné z: http://web.tuke.sk/kip/main.php?om=1300\&res=1 ow\&menu $=1310$

[6] Blatný, M. (2010) Psychologie osobnosti: hlavni témata, současné prístupy. Praha: Grada.

[7] Helus, Z. (2007) Sociální psychologie pro pedagogy. Praha: Grada Publishing.

Kolář, Z., Šikulová, R. (2009) Hodnoceni žákư. Praha: Grada.

[8] Pre-school and Primary Education in the European Union. (1994) Brussels: EURYDICE European Unit.

[9] Tollingerová, D. (1971) Bellackova metoda mikroanalýzy a její formální zápis. Psychológia a patopsychológia dietata. 
[10] Vilánek, J. (2007) L. S. Vygotskij, A. N.

Leont'jev, P. J. Gal'perin, N. F. Talyzinová.

Dostupný z $\quad \mathrm{Z}$ WW:

<file:///E:/Zkoušky/Seminárnípráce-Jakub

Vilánek.htm>.

Mgr. Dominika Stolinská

Katedra primárního vzdělávání

Pedagogická fakulta UP

Žižkovo nám. č. 5

77140 Olomouc, ČR

Tel: +420 585635109

E-mail: Dominika.Stolinska@gmail.com

Www pracoviště: http://kpv.upol.cz/

\author{
Mgr. Pavlína Nakládalová \\ Katedra primárního vzdělávání \\ Pedagogická fakulta UP \\ Žižkovo nám. č. 5 \\ 77140 Olomouc, ČR \\ Tel: +420 585635108 \\ E-mail: pavlina.nakladalova@upol.cz \\ Www pracoviště: www.kpv.upol.cz
}

